\title{
SALAT DAN TERAPI PROBLEMATIKA PSIKOLOGIS MANAJER DAKWAH
}

\author{
Ahmad Hidayat \\ STID Al-Hadid, Surabaya \\ ahmadhidayat.alhadid@yahoo.com
}

\begin{abstract}
Abstrak: Fokus kajian dalam studi ini adalah: (1) tantangan dan masalah psikologis yang dihadapi manajer dakwah, meliputi sebab, dampak bagi moril/keberanian, spirit/semangat perjuangan dalam melakukan syiar ajaran Islam, (2) esensi, fungsi, serta peran salat bagi pemecahan masalah/hambatan psikologis manajer dakwah dalam sejarah Nabi, (3) teknis memfungsikan salat untuk mengatasi berbagai hambatan yang dihadapi manajer dakwah. Pendekatan teori yang digunakan adalah psikologi existensial dengan teknis logoterapinya. Studi ini secara metodologi menggunakan studi literature. Adapun kesimpulan yang didapatkan: pertama, bahwa besarnya tanggung jawab, dinamika kerja, tantangan, dan hambatan yang dihadapi manajer dakwah dalam mengelola organisasi dakwahnya akan menekan secara psikologis (menciptakan kejenuhan, ketakutan gagal/ancaman kompetitor) bahkan menimpulkan sikap keputusasaan bila tidak tepat dalam memaknai stressor tersebut. Manajer dakwah perlu memaknai stressor tersebut sebagai sesuatu yang bermakna (hukum alamiah untuk melakukan perubahan, akan mengantarkan ke cita-cita dan mendapatkan ganjaran surga) bukan sesuatu yang mengancam saja. Kedua, salat adalah sistem yang senantiasa memberikan kesadaran secara teratur melalui perbandingan antara: (a) besarnya/sulitnya hambatan dakwah dengan kebesaran/kekuasaan Allah, (b) kerasnya perjuangan dengan siksa neraka bila berputus asa dengan meninggalkan kewajiban berdakwah, (c) pengkondisian kebebasan lingkungan yang dapat melalaikan/meredupkan semangat dalam menyebarkan ajaran tauhid dengan siksa jahanam dan jaminan surga bila tak pernah berputus asa dan konsisten dalam berdakwah. Ketiga, dalam teknis salat terdapat mekanismemekanisme pembangkitan kesadaran makna dibalik kesulitan, bencana, ancaman yang dihadapi para manajer dakwah.
\end{abstract}

Kata kunci: salat, manajer dakwah, logoterapi

\begin{abstract}
The focuses of this study are: (1) psychological challenges / problems encountered by da'wah managers, including cause, impacts for morale / bravery, spirit / enthusiasm on struggling for Islamic propagation, (2) essence, function, and role of salat for solving psychological problems / obstacles of da'wah manager in Prophet's history, (3) technical procedures functioning salat to overcome various obstacles encountered by da'wah manager. It constitutes a literature study, using the approach of theory of existential psychology with its logotherapy. It concludes: first, that the magnitude of responsibility, the dynamics of work, challenges encountered by da'wah manager in managing the da'wah organization will be psychological pressures (creating saturation, fear of failure / threat of competitor) and even create an attitude of despair if the stressor is interpreted inappropriately. A da'wah manager needs to interpret stressor as something valuable (natual law on doing a change, will lead to the dream and gain the reward of heaven) not as a threat. Second, that salat is a system which provide regular awareness through comparisons between : (a) the magnitude / difficulty of da'wah obstacle and the God's omnipotence, (b) the hard struggle and the punishment of hell if he is in despair by leaving the obligation of propagating / doing da'wah, (c) conditioning the freedom of environment which can neglect the spirit for spreading the teaching of tawhid by the punishment of severe torture of hell and the guarantee of heaven
\end{abstract}


if he is never in despair and is consistent in doing propagation / da'wah. Third, in technical procedure of salat, there is a mechanism of raising the meaning awareness behind any difficulties, disasters, threats which might be encountered by the da'wah manager.

Key words: salat, da'wah manager, logotherapy

\section{Pendahuluan}

Salat secara historis diturunkan kepada Nabi Muhammad yang saat itu melaksanakan fungsi-fungsi manajemen dakwah Islam, disamping juga untuk kaum mukmin lainya. Hal ini mengisyaratkan betapa berat beban yang dihadapi Nabi sebagai pimpinan organisasi dakwah saat itu dan para pemimpin dakwah di kemudian hari, diperlukan suatu pemecahan masalah secara profesional, sehingga Allah Swt. sendiri yang menyampaikan perintah tersebut kepada Nabi. Hal tersebut tidak terlepas dari peran penting sang manajer dakwah untuk perkembangan gelora syiar Islam, agar senantiasa optimis, tidak pernah putus asa, dan terus dinamis, bukan sebaliknya, yaitu: (a) mudah jenuh; (b) terpengaruh pengkondisian budaya kebebasan yang dapat melalaikan misi dakwah Islam; (c) merasa takut terhadap ancaman dan tekanan musuh dalam dakwah, dimana dalam sejarah ancaman dan tekanan tersebut sampai pada tataran siksaan dan pembunuhan.

Dewasa ini banyak perhatian terhadap problematika psikologi para manajer profesional (kaum eksekutif). Hingga berkembang berbagai teknik dan metode reduksi stres terhadap kaum eksekutif tersebut, yang jamak diketahui misalnya dengan teknik meditasi dan yoga. Tidak jarang umat Islam mengikuti berbagai metode tersebut, padahal Islam telah mengajarkan teknik dan metode tersendiri pada empat belas abad yang lalu melalui perintah salat, dan dilembagakan menjadi bioritme kehidupan sehari-hari kaum mukmin. Fenomena ini terjadi karena salat mungkin belum digali khasiatnya secara psikologis bagi kaum eksekutif pada organisasi dakwah. Keutamaan menjadikan salat sebagai terapi psikologis manajer dakwah adalah karena telah dilembagakannya dalam bioritme kehidupan individu, bioritme kelompok bila salat berjamaah, bioritme sosiologis melalui Salat Jumat, bahkan bioritme tahunan kenegaraan melalui Salat Idul Fitri dan Idul Adha.

Dari pertimbangan diatas maka penting untuk mengkaji tiga hal berikut, yaitu: (a) problematika manajer dakwah dalam menjalankan misi syiar Islamnya, serta apa dampaknya bagi kesehatan mentalnya, moril dan spirit perjuangan syiar Islamnya; (b) esensi salat, fungsi serta peran bagi pemecahan terhadap masalah/hambatan yang dihadapi Nabi selaku manajer dakwah (dalam sejarah turunnya perintah salat); (c) teknis memfungsikan salat untuk mengatasi berbagai hambatan yang dihadapi manajer dakwah berbasis individu dan perusahaan/organisasi. Dengan demikian tujuan dari studi ini adalah untuk: (a) mendeskripsikan problematika psikologis yang dihadapi manajer dakwah dalam menjalankan misi syiar Islamnya; (b) mendeskripsikan esensi, fungsi, serta peranan salat bagi pemecahan masalah dalam konteks sejarah turunnya; (c) mendeskripsikan teknis memfungsikan 
salat untuk mengatasi berbagai hambatan yang dihadapi manajer dakwah berbasis individu dan perusahaan/organisasi.

Studi ini secara metodologi menggunakan pendekatan literatur. Metode yang digunakan untuk memecahkan rumusan masalahnya yang pertama adalah dengan cara menggambarkan deskripsi pekerjaan manajer, kedudukan dan tanggung jawab, serta tantangan yang dihadapinya. Sedangkan untuk mengetahui esensi salat melalui deskripsi latar belakang dan tujuan perintah salat, teknis dan dampak dari perintah tersebut, khususnya bagi Nabi dalam Alquran dan sejarah. Sedangkan metode yang digunakan untuk memecahkan persoalan teknis menfungsikan salat untuk mengatasi berbagai hambatan yang dihadapi manajer dakwah menghubungkan esensi perintah salat, teknis nya untuk mencegah dan mengatasi hambatan psikologis manajer dakwah. Dasar teoritis yang dijadikan pijakan dalam studi ini adalah teori terapi eksistensial atau logoterapi dan terapi kognitif, yang dapat diterapkan dalam konteks salat sehingga mampu menjadi terapi problematika psikologis bagi manajer dakwah.

\section{Psikologi/Terapi Eksistensial (Logoterapi)}

Logoterapi merupakan metode terapi psikologis yang dkembangkan Victor Frankl, yang menjadikan eksistensi kebermaknaan manusia sebagai dasar filosofisnya. Bahwa manusia adalah makhluk yang memiliki kebebasan kehendak dan menginginginkan kebermaknaan, orientasi kepada makna itulah yang bisa membawa manusia pada konfrontasi dengan makna hidupnya, dari situlah individu bisa berkembang dan mencapai kematangannya. Makna hidup bila berhasil ditemukan dan dipenuhi akan membawa pada keberartian diri dan penghayatan kebahagiaan. Dan makna hidup yang bersifat mutlak, universal dan ultimate adalah pandangan ideologi tertentu atau Ketuhanan (agama). Di dalam logoterapi, pasien dikonfrontasikan dengan makna-makna dan ditantang untuk mendapatkan pemenuhannya. Pada pasien yang merasakan ketidakbermaknaan hidup dengan gejala refleksi dan intensitas kecemasan/ketakutan/kesedihan yang berlebihan, maka dianjurkan melakukan derefleksi, yakni mengabaikan gejala-gejala yang mengganggu dan mengalihkannya dengan tugas tertentu dalam hidup atau dikonfrontasikan kepada makna keberadaannya. Dalam kehidupan yang menderita dan terpuruk sekalipun, manusia tetap bisa menemukan makna hidup, pasien dianjurkan merealisasikan nilai bersikap yang menunjukkan keberanian menghadapi penderitaan, misalnya dengan memahaminya dari sudut pandang lain, mengambil hikmah, dsb sehingga bisa menemukan makna dari penderitaan tersebut. ${ }^{1}$ Dengan demikian ada tiga konsep dasar dari psikologi eksistensial (logoterapi) yaitu, pertama, bahwa hidup itu pasti memiliki makna, baik dalam suka maupun duka, hal ini akan mendorong manusia untuk menemukan tujuan hidupnya, kedua, makna hidup itu dapat ditemukan dalam pekerjaan atau karya yang dihasilkan, ketiga, setiap manusia memiliki kemampuan untuk mengambil sikap atau mengubah sikap terhadap penderitaan dan peristiwa yang tragis yang tidak mungkin mampu dirubahnya.

1 E. Koeswara, Logoterapi Psikoterapi Victor Frankl, (Yogyakarta: Kanisius, 1992). 
Munculnya perpektif baru oleh Viktor Frankl dalam penanganan gangguan psikologis ditengah situasi penuh ketidakpastian akibat situasi krisis (Perang dunia satu dan dua), mendorong pendekatan baru untuk hidup lebih nyaman di muka bumi yang extrim pada saat itu. Akhirnya melalui pengalaman pribadi Viktor Frankl menemukan kembali kebahagiaan hidupnya dalam situasi camp penyiksaan yang dilakukan rezim Nazi, karena ia mampu menemukan makna hidup dibalik semua yang menimpa dirinya pada saat itu. Bahkan dalam pandangannnya, sejatinya makna hidup itu lah yang dicari manusia dibalik perasaan kecemasan, ketakutan dan rasa putus asanya, bukan rasa bahagia. Individu memerlukan energi yang supra (melampaui) semua kesulitan yang dihadapi selama ingin mencapai kebahagiaan dan kesejahteraan yang semakin kompetitif, dinamis dan tidak jarang kejam. $^{2}$

Logoterapi sebagai suatu terapi mengatasi hambatan psikologis dengan menemukan/mengubah makna dibalik bencana yang dialami adalah dihubungkan dengan eksistensinya (makna hidupnya). Cara individu menemukan dan mengubah persepsi terhadap stressor yang akan mempengaruhi reaksi psikologisnya. Substansinya adalah pada cara berpikir terhadap stressor. Dari sini terapi kognitif (berpikir) yang digagas oleh David Burn dapat digunakan. Burns menjelaskan bahwa prinsip-prinsip terapi kesadaran atau kognisi, ada beberapa hal antara lain: pertama, bahwa semua rasa cemas diciptakan oleh pikiran. Hal ini ditentukan oleh cara pandang orang terhadap suatu

\footnotetext{
2 lbid.
}

keadaan. Maka apa yang dirasakan adalah yang di pikirkan. Kedua, dalam keadaan depresi atau tekanan jiwa maka seseorang dikuasai oleh suatu kenegatifan yang mendalam. Ketiga, pemikiran yang negatif akan menyebabkan kekacauan emosional sehingga hanya berfokus pada kesimpulan itu saja, walaupun pemikiran itu valid. Ini yang menyebabkan orang tidak mampu keluar dari persoalan, karena ia larut akan bencana yang akan ditimbulkan. ${ }^{3}$

Terdapat empat tahap dalam existensial analysis pada logoterapi sebagaimana disampaikan Elisabeth Lukas yang dikenal sebagai The four steps of logotherapy yaitu, ${ }^{4}$ pertama, mengambil jarak atas simtom (distance from symptoms). Pendekatan ini berusaha mengajak seorang pasien/klien untuk keluar dari ketidakberdayaannya terhadap situasi yang membelitnya, dengan membuka pandangan baru diluar pandangannya dan mencoba untuk melihat beban persoalan itu sebagai sesuatu yang bisa diatasi dengan membuka kesadaran akan kemampuan yang lain yang dimilikinya. Kedua, modifikasi prilaku (modification of attitudes). Prinsip ini terkait dengan bagaimana seorang klein mampu membangun kepercayaan dirinya, sehingga mampu bersikap dengan penuh tanggungjawab. Maka seorang terapis diharapkan memberikan masukan sikap positif kepada kleinnya, bukan membiarkan dirinya semakin tidak percaya diri lantaran tidak mampu bersikap terhadap persoalan yang membelit perasaan dan jiwanya.

\footnotetext{
${ }^{3}$ David D. Burns, Terapi Kognitif: Pendekatan Baru Bagi Penanganan Depresi, diterjemahkan Santosa, (Jakarta: Erlangga, 1988) 5-6.

4 Hanna Djumhana Bastaman, Meraih Hidup Bermakna: Kisah Pribadi Dengan Pengalaman Tragis, (Jakarta: Paramadina, 1996), 43-44.
} 
Ketiga, pengurangan simtom (reducing simptoms). Tahap ini adalah upaya mengurangi beban-beban psikologis yang dirasakan oleh klien dan terapis membantunya untuk proses berkurangnya tekanan tersebut. Mengurangi simtoms kecemasan menurut Dale Carnigie juga bisa dengan jalan menerima kenyataan atau keadaan yang memang kita tidak mampu untuk menghindarinya. ${ }^{5}$ Keempat, orientasi terhadap makna (orientation toward meaning). Tahap ini adalah tahap untuk mengembangkan dan memproduksi nilainilai dan pemaknaan tentang hidup, dan diperdalam serta diperluas untuk mencapai tujuan-tujuan yang lebih kongkret.

\section{Problematika}

Manajer

Dakwah dan Dampaknya bagi Kesehatan Mental, Moril dan Spirit Perjuangan Syiar Islamnya.

Manajer profesional termasuk manajer organisasi dakwah profesional secara umum adalah orang yang mengelola dan mengembangkan modal SDM, finansial, produk dan sumber daya selainnya yang dimiliki organisasi serta mempertanggung jawabkannya kepada komisaris, pemilik perusahaan. Manajerlah orang yang bertanggung jawab kepada komisaris terhadap semua yang terjadi pada perusahaan/organisasi, meskipun bukan dia secara langsung melakukan kesalahan sehingga terjadi kepailitan atau kemunduran organisasi. Manajer dalam mencapai tujuannya melalui para stafnya. Para staf tidak jarang memiliki beragam

${ }^{5}$ Dale Carnigie, Bagaimana Menghilangkan Cemas \& Memulai Hidup Baru, (Surabaya: Usaha Nasional, t.t.), 112. motivasi, karakter, moral kerjasama yang berbeda-beda. Mereka diletakkan pada bidang tertentu dan memiliki hubungan struktural dan kerja. Disana akan bisa ketahui adanya beragam dinamika yang dihadapi manajer, apalagi bila organisasi mengalami perkembangan, bahkan beradaptasi terhadap kompetisi dan perubahan zaman/perilaku konsumen, perubahan regulasi, dan lain-lain. Masalah penempatan SDM yang tepat, menghadapi konflik antar SDM, konflik staf dengan manajer sendiri, motivasi kerja yang tidak memadai, pengendalian kerja. Semua masalah itu harus dihadapi dan manajerlah yang bertanggung jawab terhadap semua persoalan dan pemecahan SDM. Dinamika masalah sektor SDM dan pemecahannya itu akan lebih komplek lagi bila organisasi mengalami perkembangan, bahkan beradaptasi terhadap kompetisi dan perubahan zaman/perilaku konsumen, perubahan regulasi.

Dinamika dirinya sebagai manajer serta keluarganya pun cukup dinamis baik ketika organisasi dakwah saat merintis demikian juga pada saat mengalami kemajuan yang pesat. Saat masa susah ketika sedang merintis semua serba terbatas, ada tuntutan memperhatikan diri dan keluarga nya sambil tetap fokus terhadap pengembagan organisasi dakwahnya. Ada persoalan keterbatasan yang harus dihadapi, tuntutan, fokus dan tuntutan keseimbangan yang harus dijaga. Semua itu harus profesional dihadapinya, kadang semua kesusahan dan kesedihan yang dihadapi tidak menampak dan tetap menampakkan kefokusan dan senantiasa memotivasi dan mengisipirasi semuanya untuk terus bisa mengerjakan perkerjaan 
masing-masing dengan baik dan terus dinamis mengembangkan organisasi.

Dinamika diri sebagai manajer dan keluarganya tidak berhenti saat organisasi mengalami kemajuan. Disamping banyaknya mad'uw yang mengikuti kajian dakwahnya, dana lebih besar akan diperolehnya karena meningkatkan peserta dan donatur sangat percaya karena melihat kinerja organsasi nya. Bagaimana tetap dapat fokus pengembangan kemajuan, sambil tetap seimbang dengan stimulus modal finansial yang begitu 'melimpah' dalam menghadapi tuntutan diri dan keluarganya. Dan para manajerlah yang menentukan dan bertanggung jawab terhadap kemajuan sambil bisa mengatasi secara seimbang terhadap tuntutan diri, dan keluarga.

Dinamika eksternal meliputi mengikuti regulasi yang ada. Di era yang begitu dinamis, regulasi pun sering mengikutinya. Regulasi tema yang sensitif, kriteria dai, ijin pengadaan kegiatan dakwah yang melibatkan masa, dan lain-lain, terus mengalami perubahan. Itu semua akan mempengaruhi tatanan produk materi, manajemen pengadaan kegiatan dakwah dan perhatian harus terus menerus mengikuti perkembangan regulasi tersebut. Dinamika eksternal yang bersumber dari kompetitor. Tidak jarang organisasi dakwah menerima fitnahan dari selainnya. Bila suatu masyarakat etika kompetisinya segala cara, misalnya dengan menyebar berita hoax jamak dilakukan untuk menjatuhkan pesaingnya maka, manajer harus membuat tatanan materi, pemasaran kegiatan, ijin, dan lain-lain, harus bisa menghindari fitnahan tersebutManajemen krisis pun harus disiapkan karena tidak jarang sekalipun sudah diantisipasi fitnah masih saja bisa terjadi. Hal ni dirasakan manajer menuntut tidak hanya respon yang tepat, tapi juga cepat. Sebab semua hal tersebut masuk wilayah tangungjawab manajemen.

Dari uraian diatas dapat dirangkum berbagai problema yang dihadapi manajer dakwah, dapat disimpulkan tingginya tekanan, dinamika, kompleksitas masalah yang kesemua masuk tanggung jawabnya. Apalagi itu semua menuntut respon cepat dan tepat. Tidak jarang masalah tidak bisa segera dijawab, walaupun berkali-kali diupayakan pemecahannya, belum lagi kalau sudah mengalami komplikasi, itu semua masih dalam wilayah tanggung jawabnya. Manajer tentunya bukan mesin yang tidak memiliki perasaan, kejenuhan, dan sebagainya. Dalam menghadapi dinamika persoalan diatas tentunya akan mempengaruhi psikologisnya, baik berupa gangguan kecemasan/ketakutan, kesehatan mental, moril kerja yang menurun, kejenuhan, tidak jarang perasaan putus asa menghinggapinya.

Maka diperlukan suatu terapi yang mampu mengembalikan kondisi para manager dari keterpurukan psikologis dengan memfungsikan salat sebagai sebuah terapi kesadaran untuk me-refrseh mental sehingga mampu menghadapi tekanantekanan psikologis. Memang ada berbagai macam cara untuk mereduksi stress yang menimpah seorang manager, khususnya di Indonesia banyak diantara mereka yang menyalurkan stress dengan melakukan salat, meditasi atau yoga. ${ }^{6}$ Justru bagi umat Islam, salat tahajud dan zikir yang

${ }^{6}$ Candra Gautama, Ed., Hidup Sehat bagi Eksekutif: Stress, Seks, dan Keluarga, (Jakarta: Kompas, 2000), 7-8. 
dikerjakan malam hari secara khusyuk akan menjadi jalan meditasi transendental yang memperkuat dengan rasa pasrah dan berharap pertolongan Allah.

Selama ini individu memandang bahwa energi untuk menghadapi tuntutan hidup ini adalah reward dibalik kerja keras untuk mendapatkan posisi tinggi yang bergelimang material dan fasilitas lainnya. Namun setelah itu diraihnya dia kembali bertanya untuk apa ini semua saya dapatkan, sementara individu butuh energi yang senantiasa ada dan memadai, baik saat sukses maupun gagal agar esok bisa terus berkompetisi, agar dapat meraih semua penghargaan material, sosial dan moral. Dalam pandangan psikologi existensial, kesemua stressor yang dihadapi oleh manajer bukan sebab perasaan tidak bahagia, cemas, takut, bahkan sampai menimbulkan perasaan putus asa. Sehingga solusinya bukan dengan meninggalkan pekerjaan manajernya dan memfokusnya pada kebahagiaan diri dan keluarganya, melainkan para manajer tersebut harus menemukan makna dibalik profesi dan dinamika stres dalam profesinya tersebut. Kaca mata psikologi existensial dalam memaknai fenomena tantangan psikologis manajer dakwah, pun demikian. Bahwa perasaan yang secara pribadi dirasakannya sebagai kesengsaraan-bencana psikologis yang dihadapi para manajer dakwah adalah bukan karena dinamika internal organisasi, tekanan kompetitor, dinamika global dan sulitnya melakukan keseimbangan dengan tuntutan individu dan keluarganya, melainkan ketidakmampuannya menemukan makna hidup dibalik profesi dan dinamika profesinnya tersebut.

\section{Esensi, Fungsi dan Peran Salat bagi Pemecahan Masalah dalam Sejarah Nabi sebagai Manager Dakwah.}

Nabi sebagai manager dakwah yang mengemban risalah untuk melakukan pembangunan masyarakat dimekkah maupun dimadinah banyak mendapatkan tantangan, hambatan, ancaman dan gangguan bukan hanya pada aspek fisik, tapi juga psikis beliau. Sebagai seorang manager dakwah nabi mendapatkan dari berbagai pihak, tekanan bisa dari umat berupa persoalan-persoalan internal organisasi dakwah, lingkungan masyarakat jahiliyah mekkah saat itu, orang-orang Quraisy yang manjadi kompetitor dakwah nabi yang berusaha selalu melemahkan upaya-upaya nabi mendakwahi orangorang mekkah saat itu.

Bahkan upaya-upaya mendiskriditkan nabi sampai upaya-upaya embargo ekonomi, komunikasi masih sanggup beliau hadapi dengan tegar karena masih ada dua tokoh yang mem-back up beliau baik secara politik maupun secara ekonomi, yaitu pamannya Abu Thalib dan istrinya Khatijah. Khususnya khadijah, bagi nabi istrinya itu bukan sekedar wanita yang mampu mendukung secara finansial tetapi juga secara psikis, imannya yang kuat ditambah cintah kasih dan kejujuran adalah sesuatu kekuatan yang mampu menghalau dan menghilangkan kesedihan hati akibat siksaan musuh-musuhnya. ${ }^{7}$ Berbagai upaya boikot dan pengepungan terhadap nabi dan kaum muslimin hampir sekitar tiga tahun, namun hal itu tidak menghentikan nabi dan

7 Muhammad Husain Haikal, Sejarah Hidup Muhammad, diterjemahkan Ali Audah, (Jakarta: Litera Antarnusa, 2010), 101. 
kaum muslimin untuk tetap mendakwahkan Islam kepada penduduk mekkah. ${ }^{8}$ Embargo sosial, yang dilakukan oleh orang-orang Quraisy membuat nabi dan kaum muslimin tidak bisa menjalankan dakwah,karena semua bani-bani dimekkah dilarang keras untuk berkomunikasi dengan nabi dan kaum muslimin, kecuali pada bulan-bulan suci, sehingga dalam bulanbulan itu nabi dan sahabat-sahabatnya melancarkan dakwahnya kepada para kabilah-kabilah Arab. ${ }^{9}$

Ketika kedua orang tersebut meninggal dunia Nabi sangat terpukul dan merasa tidak siap secara mental, sehingga perasaan tertekan sangat mendalam dirasakan nabi. Abu Thalib pamannya adalah seorang yang masih dihormati oleh para elite Quraisy dan tentunya orang-orang mekkah yang memusuhi nabi masih sangat hormat kepada pamannya itu. Sehingga kematian pamannya ini membuat tidak adalah lagi penghalang untuk melakukan apa saja kepada diri muhammad, sebab selama ini beliau yang menjadi pelindung dan perisai nabi. ${ }^{10}$ Sedangkan Khadijah adalah seorang yang mampu menggerakkan hati dan kasih sayangnya mampu mendorong rasa percaya diri nabi. Khadijah ibarat bidadari yang selalu dengan kasih sayangnya menghibur, menguatkan mental dan menghilangkan rasa takut, kawatir dan kesedihan. ${ }^{11}$ Meninggalnya kedua orang tersebut membuat Nabi kehilangan kesimbangan mentalnya, mengalami frustasi, kesedihan mendalam, dan dikuasai rasa takut sehingga menjadi lemah secara

\footnotetext{
8 Ibid., 147.

9 Ibid.

10 lbid., 152.

11 lbid.
}

mental, tidak mampu berpikir lain diluar peristiwa duka tersebut. ${ }^{12}$

Nabi semakin tidak percaya diri, bimbang dan mungkin mendekati putus asa untuk manjalankan dakwah di tanah kelahirannya, bahkan bermaksud bermaksud meninggalkan dakwahnya di Mekkah dan berusaha mencari medan dakwah yang lain, saat itu pilihannya jatuh pada sebuah kota yang dekat dengan mekkah, yaitu Thaif. ${ }^{13}$ Ini karena semua usaha dan upaya yang dilakukan seolaholah membentur dinding tebal yang berujung kesulitan dalam mengembangkan dakwahnya di Mekkah. Walaupun upaya mengalihkan medan dakwah ke Thaif berujung pada pengusiran. Bahkan keadaan ini seperti digambarkan oleh firman Allah Swt. dalam surah Alisra' ayat 74-75.

"Dan kalau Kami tidak memperkuat (hati)mu, niscaya kamu Hampir-hampir condong sedikit kepada mereka, Kalau terjadi demikian, benar-benarlah Kami akan rasakan kepadamu (siksaan) berlipat ganda di dunia ini dan begitu (pula siksaan) berlipat ganda sesudah mati, dan kamu tidak akan mendapat seorang penolongpun terhadap kami. ${ }^{14}$

Sehingga dakwah Nabi benar-benar mengalami krisis yang mengancam keberlangsungan organisasi dakwah Islam. Hal tersebut setidaknya dapat diidentifikasi melalui beberapa fakta penting berikut: (a) besarnya peran Abu Thalib dalam memberikan perlindungan kepada Nabi secara fisik/jaminan keamanan dan dukungan sosial, (b) besarnya peran istri

\footnotetext{
$12 \mathrm{lbid}$.

${ }^{13}$ S. Anwar Effendie, Isra' Mi'raj: Perjalanan Ruang Waktu Dalam Kaitannya Dengan Penciptaan Alam Raya, (Jakarta: Pradnya Paramita, 1993), 7.

${ }^{14}$ Departemen Agama RI (Depag RI), Alquran dan Terjemahannya, QS. 17:74-75.
} 
Nabi, Khadijah, dalam mendukung dan menghibur Nabi dalam kesulitan dakwah, (c) sepeninggal Abu Thalib, Bani Hasyim, kabilah asal $\mathrm{Nabi}$, tidak lagi memberikan perlindungan kepada Nabi, (d) meningkatnya tekanan secara fisik kepada Nabi dari orang-orang kafir Quraisy yang sudah mengarah pada upaya pembunuhan, (e) upaya dakwah Nabi memindahkan medan dakwah di Thaif namun menuai kegagalan yang menyakitkan. ${ }^{15}$ Tekanan demi tekanan dari para kompetitor dakwahnya semakin lama semakin besar dan membuat Nabi semakin tertekan dan ingin menyendiri, sampai kemudia Allah meng-Isra Mikrajkan beliau sekitar tahun 621 Masehi. ${ }^{16}$

Dalam peristiwa Isra Mikraj, Nabi di tunjukkan suatu kebesaran Allah, kekuasaan dan keagungan-Nya, ditunjukkan gambaran surga dan neraka, diperintahkan untuk menjalankan salat lima waktu dan dipertemukan dengan para nabi. Sebagaimana digambarkan oleh Allah sebagaimana firman-Nya dalam surah Alisra' ayat 1.

"Maha suci Allah, yang telah memperjalankan hamba-Nya pada suatu malam dari Al Masjidil Haram ke Al Masjidil Aqsha yang telah Kami berkahi sekelilingnya agar Kami perlihatkan kepadanya sebagian dari tanda-tanda (kebesaran) kami. Sesungguhnya Dia adalah Maha mendengar lagi Maha mengetahui." ${ }^{17}$

Pada peristiwa Isra Mikraj inilah Nabi diperlihatkan lewat sebuah perjalanan luar

${ }^{15}$ Dedy Pradesa, "Dakwah Rasul Menjelang Hijrah: Strategi Dakwah Menghadapi Krisis," Jurnal Kajian dan Pengembangan Manajemen Dakwah, Vol. 06, No. 01, (Juni, 2016): 154.

16 Haikal, Sejarah Hidup., 157.

17 QS. 17:1. biasa dalam rangka memberikan penguatan secara mental akan kebesaran dan kekuasaan Allah yang menguasai seluruh alam raya, dipertemukan dengan para nabi yang sama-sama mengembang misi pembangunan masyarakat pada zamannya, dan juga diperlihatkan betapa luar biasanya siksa akherat dan kenikmatan surga yang dijanjikan Allah kepada hamba-hambanya yang menjalankan misinya. Semua ini bermaksud bahwa apa yang disampaikan oleh nabi adalah kebenaran dan pertolongan Allah pasti akan diperoleh jika selalu berketetapan hati untuk berjuang di jalanNya.

Analoginya jika seseorang menghadapi tekanan mental yang luar biasa dan diambang putus asa akibat menghadapi musuh yang sangat tidak berimbang, kemudian ada seseorang dengan kekuatan yang melebihi musuhnya maka tentunya mental orang tersebut akan kembali percaya diri dan bangkit untuk berjuang dan melakukan perlawanan. Dalam perjalan tersebut nabi juga menyaksikan visualisasi keadaan surga dan neraka, dimana hal ini akan menjadi sebuah kekuatan tersendiri kepada mental nabi, bahwa janji dan sangsi Allah adalah kebenaran yang nyata, sehingga ini akan menguatkan jiwanya dalam menghadapi tantangan dakwah. Pertemuan dengan para nabi-nabi juga memberikan kekuatan bahwa Muhammad tidak sendiri dalam menerima konsekwensi logis akan tantangan perjuangan sebagaimana dialami oleh para nabi sebelumnya. Dan juga yang terpenting, yang bersifat lebih permanen adalah diperintahkannya Nabi menjalankan salat lima waktu. 
Dari uraian sejarah singkat di atas dapat dianalisis bagaimana esensi, fungsi dan peranan salat, khususnya dalam kaitannya dengan pemecahan masalah psikologis Nabi sebagai manajer dakwah kala itu.

\section{Eseni Salat}

Salat adalah sebuah aktivitas ibadah yang diawali dengan takbir dan diakhiri dengan salam, dan kalau ditinjau maknanya terdiri dari ikrar pemujaan, pengabdian dan permohonan. ${ }^{18}$ Perintah salat dalam Alquran surah Tahaa ayat 14 berbunyi, sesungguhnya aku ini adalah Allah, tidak ada Tuhan (yang hak) selain Aku, Maka sembahlah aku dan dirikanlah salat untuk mengingat aku. ${ }^{19}$ Mengacu pada ayat tersebut maka salat dalam Alquran memiliki tujuan untuk mengingat Allah. Arti mengingat Allah memiliki berbagai penafsiran antara lain yaitu: ${ }^{20}$ (a) mengingat Zat-Nya; (b) mengingat sifatsifatNya; (c) mengingat kenikmatankenikmatan dan ancaman/siksa Allah; (d) mengingat sunnatullah yang diberlakukanNya.

Dengan jalan mengingat Allah melalui salat dengan penafsiran dan pemaknaan diatas maka akan membuka kesadaran dan makna hidup. Dalam salat juga terkandung do'a yang selalu dipanjatkan dan diulang-ulang dalam setiap rakaatnya, hal ini akan menimbulkan sugesti dan upaya-upaya untuk memikirkan persoalan-persoalan secara mendalam diluar kegiatan salat. Doa yang dipanjatkan secara khusyuk dan merupakan sebuah jeritan atas ketidakberdayaan akan menimbulkan

\footnotetext{
${ }^{18}$ Iskandar Al-Warisy, "Potensi Unsur Sholat dalam Memecahkan Masalah" dalam Pemikiran Islam Ilmiah Buku-2, (Surabaya: Yayasan Al-Kahfi, 2012), 287.

19 QS. 20:14.

${ }^{20}$ Al-Warisy, "Potensi Unsur.," 279.
}

energi positif secara mental akan mendatangkan semangat dan kekuatan mental bagi yang melakukannya, dan tentunya tidak menutup kemungkinan adanya pertolongan Allah.

Sehingga esensi yang terkandung dalam salat adalah pembentukan kesadaran mental dan mendorong sugesti positif sehingga mendorong upaya-upaya untuk mencari pemecahan masalah diluar salat lewat ilmu-ilmu terkait dengan jalan memikirkannya secara mendalam atau dalam bahasa Alquran dikatakan zikir. Salat yang ujungnya perintah berpikir (zikir) dalam psikologi eksistensial digunakan untuk membuka kesadaran dalam membentuk makna hidup yang positif. Makna hidup menurut logoterapi merupakan tujuan baik dalam kondisi senang maupun susah. Sehingga tergantung bagaimana seseorang memaknai sesuatu peristiwa ketika peristiwa tersebut menghampirinya.

\section{Fungsi dan Peranan Salat}

Untuk memahami fungsi dan peranan salat maka tentu perlu memahami unsur-unsur yang terkandung dalam kegiatan salat. Ada beberapa unsur-unsur yang ada dalam kegiatan salat antara lain: ${ }^{21}$ pertama, pra salat, meliputi: (a) waktunya: subuh, zuhur, ashar, magrib dan isya; (b) berwudhu yaitu membersihkan bagian-bagian tubuh; (c) menghadap kiblat; (d) dilakukan dengan penuh kekhusyuan; (e) awali dengan panggilan salat (adzan). Kedua, saat salat, meliputi: (a) mlakukan gerakan mengangkat tangan, rukuk, sujud, l'tidal dan seterusnya; (b) melakukan seruan diantaranya memuji Allah, berikrar, berdoa

\footnotetext{
21 Ibid., 286.
} 
dan membaca ayat-ayat Alquran. Ketiga, bentuknya, meliputi salat sendiri dan salat berjemaah. Keempat, jenisnya, meliputi: (a) salat rawatib, bersifat harian; (b) salat Jumat, bersifat mingguan; (c) salat Idul Fitri atau Idul Adha; (d) salat gerhana, dan lainlain.

Dari unsur-unsurnya bisa dijelaskan tentang fungsi dan peranannya. Adapun penjelasan bisa diuraikan berdasarkan unsur-unsurnya yaitu:

a) unsur pra salat

Persiapan salat yang terdiri dari ber wudhlu, tempat yang bersih dan jika salat dilakukan secara berjemaah dimasjid atau mushallah biasanya didahulu oleh adzan. Tetapi mungkin penulis hanya akan menjelaskan sedikit tentang salah satu persiapan pra salat yaitu wudhlu. Wudhlu menurut Moh. Ali Aziz, mengatakan bahwa wudhlu bukan semata-mata membersihkan fisik tetapi juga membersihkan bathin, karena dalam aktivitas berwudhlu terdapat dua unsur yaitu membersihkan fisik dan terkandung doa, istighfar dan taubat. ${ }^{22}$ Sehingga dengan didahului membersihkan diri baik secara fisik ataupun mental seseorang yang akan menjalankan salat memiliki kesiapan dan sadar akan melakukan aktivitas pembentukan kesadaran dan kefokusan dalam menjalankannya.

\section{b) unsur bacaan}

Adapun bacaan dalam salat secara umum, diperintahkan membaca surah Alfatihah yang wajib dibaca dalam setiap salat yang isinya adalah tentang pernyataan kebesaran dan kemurahan Allah, pernyataan tentang pengabdian hanya

22 Moh. Ali Aziz, 60 Menit Terapi Shalat Bahagia, (Surabaya: IAIN Sunan Ampel Press, 2012), 29. kepada Allah dan permohonan untuk diberikan dan ditunjukkan jalan yang lurus sebagaimana jalan kebenaran yang diperoleh oleh orang-orang yang telah mendapatkan rahmat sebagaimana jalan para nabi dan orang-orang saleh dan bukan jalan orang-orang yang dimurkai Allah. ${ }^{23}$ Dengan menyadari bahwa komitment yang diucapkan lewat surah Alfatihah itu akan membuat seseorang memiliki kekuatan dan kepercayaan diri dalam menghadapi tekanan, gangguan dan ancaman baik secara fisik maupun psikologis yang menimbulkan rasa takut, tidak percaya diri dan pada akhirnya bisa juga putus asa. Selain itu juga diperintahkan membaca surat-surat dalam Alquranyang mengisahkan tentang sejarah perjuangan para nabi, kisah-kisah orang-orang terdahulu, surga dan neraka, sehingga ini akan memberikan motivasi, kesadaran akan nilai-nilai kebenaran, ketabahan, siksa neraka dan kenikmatan surga. ${ }^{24}$

Bacaan surah-surah dalam Alquran sebenarnya bisa disesuaikan dengan kebutuhan-kebutuhan individu atau kelompok sesuai dengan masalah yang mereka hadapi. Misalnya kita menginginkan kemampuan pemikiran, materi atau teknologi mungkin kita bisa membaca ayat-ayat yang mengisahkan tentang kisah Nabi Ibrahim, Nabi Daud dan mungkin Nabi Muhammad, sehingga bisa mendapatkan pelajaran tentang bagaimana para nabi tersebut berpikir, belajar, dan bekerja keras. ${ }^{25}$ Sehingga bacaan-bacaan ini baik yang wajib ataupun yang sunnah bertujuan untuk menguatkan komitment atas sumpah yang telah diberikan sekaligus

\footnotetext{
${ }^{23}$ Al-Warisy, "Potensi Unsur.," 187.

24 Ibid.

25 Ibid.
} 
motivasi agar tidak goyah dalam menghadapi tantangan, tekanan, hambatan bahkan mungkin godaan baik harta, jabatan ataupun pasangan hidup. Maka dengan bacaan ayat-ayat tentang kisah-kisah atau informasi tersebut akan terbuka kesadaran baik itu bersifat kognitif maupun afeksi akan mendorong terbuka inspirasi, motivasi dan tekad yang kuat untuk mengambil pelajaran dan mengikuti prinsip-prinsip universalnya. ${ }^{26}$

Bacaan-bacaan dalam salat juga mengandung aspek auto sugesti, ${ }^{27}$ dimana setiap bacaan tersebut mengandung makna yang bukan hanya positif tetapi memiliki aspek membangkitkan diri bagi yang membacanya, apalagi bacaan-bacaan yang dibaca juga bermakna do'a yang berarti juga permohonan pertolongan kepada dzat yang semuanya bergantung pada-Nya. Proses salat yang terkandung bacaanbacaan yang membangkitkan pada dasarnya adalah sebuah terapi yang tidak berbeda dengan terapi self-hypnosis ${ }^{28}$. Ini akan mendorong seseorang yang melakukannya akan mengalami meningkatkannya kesadaran akan adanya Zat yang sempurna diluar dirinya. Sugesti inilaha dalam logoterapi akan membantu seseorang menemukan makna hidup dibalik pekerjaaan atau karya yang di kerjakannya.

\section{c) unsur waktu}

Secara waktu salat dalam sehari dilakukan lima waktu yaitu subuh, zuhur, ashar,

\footnotetext{
26 Ibid, 288.

27 Auto segesti adalah salah satu teknik dalam hipnotis, yaitu dengan menggunakan kata-kata positif yang diulang-ulang agar masuk alam bawah seseorang yang diterapi yang dilakukan oleh terapis. 28 Jamaluddin Ancok dan Fuat Nashori Suroso, Psikologi Islami: Solusi Islam atas Problem-Problem Psikologi, (Yogyakarta: Pustaka Pelajar, 1995), 100.
}

magrib dan isya, karena disadari bahwa orang-orang kafir selalu berusaha melemahkan orang-orang muslim yang berusaha membangun masyarakat, bahkan dalam ayat-ayat Alquran dijelaskan, "Katakanlah: "Aku berlidung kepada Tuhan (yang memelihara dan menguasai) manusia. Raja manusia. Sembahan manusia. Dari kejahatan (bisikan) syaitan yang biasa bersembunyi, Yang membisikkan (kejahatan) ke dalam dada manusia, Dari (golongan) jin dan manusia." 29

Jika merujuk pada ayat-ayat diatas jelas bahwa godaan, hambatan dan gangguan serta bisikan-bisikan jahat tidak hanya berasal dari manusia tetapi juga dari golongan jin untuk menghentikan misi keturunan adam dalam membangun masyarakat taqwa berdasarkan hukumhukum keseimbangan. Dalam logoterapi yang bertujuan menemukan makna hidup dengan meningkatkan kesadaran, maka jika kesadaran itu setiap hari dibangkitkan maka setiap pekerjaan dan karya yang dilakukan mampu dimaknai apakah hasilnya positif ataupun negatif. Bahkan hal ini bisa juga mengurangi stressor yang dihadapi oleh para menager dakwah.

d) unsur menghadap kiblat

Menghadap kiblat (Masjidil Haram) sebenarnya bertujuan lebih pada suatu upaya untuk menyatukan kaum muslimin, kesamaan kiblat sebenarnya lebih pada pertimbangan aspek internasional, kesatuan arah, sehingga umat Islam tidak mudah dipecah sekaligus menjadi kekuatan baik secara kuantitas maupun kualitas. Kekuatan tersebut akan memberikan pemecahan sosial umat Islam baik terkait dengan bantuan tenaga, keuangan, ilmu

${ }^{29}$ QS. 114:1-6. 
pengetahuan dan teknologi. Dengan kesamaan dan kesatuan kiblat akan menjadi kekuatan yang mampu membendung kedholiman orang-orang kafir. Sehingga kiblat harus dimaknai sebagai suatu arah dan gerak pemersatu kaum muslimin dalam berhubungan dengan dunia internasional, bukan dimaknai secara supranatural. Karena kiblat yang umumnya adalah sebuah monumen sejarah peradaban manusia sebagai simbol ketaatan kepada Tuhan, sekaligus juga dimasa jahiliyah bahkan digunakan oleh orang-orang kafir Quraisy untuk menyembah berhala.

Makanya umat Islam dilarang berkiblat ke masjidil haram pada saat majidil haram masih dikuasai oleh orang-orang kafir seperti bunyi ayat Allah pada surah Albaqarah ayat 143.

"Dan demikian (pula) Kami telah menjadikan kamu (umat Islam), umat yang adil dan pilihan agar kamu menjadi saksi atas (perbuatan) manusia dan agar Rasul (Muhammad) menjadi saksi atas (perbuatan) kamu. dan Kami tidak menetapkan kiblat yang menjadi kiblatmu (sekarang) melainkan agar Kami mengetahui (supaya nyata) siapa yang mengikuti Rasul dan siapa yang membelot. dan sungguh (pemindahan kiblat) itu terasa Amat berat, kecuali bagi orang-orang yang telah diberi petunjuk oleh Allah; dan Allah tidak akan menyia-nyiakan imanmu. Sesungguhnya Allah Maha Pengasih lagi Maha Penyayang kepada manusia. ${ }^{\prime 30}$

Sementara pada surah Albaqarah ayat 144, Allah juga memberikan keterangan terkait dengan kiblat.

"Sungguh Kami (sering) melihat mukamu menengadah ke langit, Maka sungguh Kami akan memalingkan kamu ke kiblat

${ }^{30}$ QS. 2:143. yang kamu sukai. Palingkanlah mukamu ke arah Masjidil Haram. dan dimana saja kamu berada, Palingkanlah mukamu ke arahnya. dan Sesungguhnya orang-orang (Yahudi dan Nasrani) yang diberi Al kitab (Taurat dan Injil) memang mengetahui, bahwa berpaling ke Masjidil Haram itu adalah benar dari Tuhannya; dan Allah sekali-kali tidak lengah dari apa yang mereka kerjakan." ${ }^{\prime 31}$

Dari ayat diatas jelas umat Islam diberikan kiblat yang berbeda dengan selainnya, dan dengan memalingkan kepada arah kiblat yang ditetapkan Allah maka umat Islam akan senang hatinya, hal ini terkait dengan kebersamaan dalam menghadap arah yang sama akan mendatangkan rasa optimis dan kekuatan moril yang luar biasa, karena jutataan umat Islam diseluruh dunia menghadap arah yang sama. Kiblat juga bisa menjadi monumen sejarah peradaban bagaimana para nabi membangun masyarakatnya ditengah-tengah lingkungan jahiliyah secara terus-menerus bahkan menjadi simbol pengingat dikalah seorang mengalami tekanan kejiwaan.

Logoterapi mengajarkan bahwa jika seseorang tidak mampu menghindari ketakutan, kecemasan dan kegelisahan maka cara terbaik adalah bukan lari dari lingkungan tersebut, tetapi merubah sikap, bahwa semua orang yang berjuang dalam dunia dakwah akan juga merasakan hal yang sama, dan tinggal bagaimana kita mensikapinya sehingga tidak berdampak negatif dan tidak menjadi beban psikologis manager dakwah. Dengan menghadap kiblat berarti memiliki kesamaan visi dan misi dalam dakwah.

\footnotetext{
${ }^{31}$ QS. 2:144.
} 
e) unsur berjamaah

Kaum muslimin diperintahkan melakukan salat secara berjemaah. Jemaah bermakna bahwa salat itu dilakukan dengan bersamasama dan dipimpin oleh seorang imam. Imam harus senantiasa diikuti dalam setiap gerakan dan makmum tidak diperkenankan melakukan gerakan mendahului imam. Hal ini bermakna bahwa dalam salat diajarkan sebuah prilaku organisasi dan kepemimpinan. Salat yang dilakukan oleh umat Islam menjadi simbol ketaatan kepada pemimpin. Dalam salat diajarkan bahwa imam haruslah orang yang memiliki ilmu lebih tinggi, moralitas lebih baik dan memiliki kemampuan dalam memimpin. Sehingga dengan salat berjemaah memberikan pelajaran berharga dalam kehidupan sosial tentang ketaatan dalam kepemimpinan. Baik di dalam dan diluar salat maka umat Islam diwajibkan untuk senantiasa mentaati kepemimpinan.

Dengan salat berjemaah umat Islam kembali diberikan kesadaran akan nilai penting kehidupan berjemaah atau bermasyarakat berdasarkan prinsip-prinsip ketaatan kepada pemimpin. Salat berjemaah merupakan cerminan bagi umat Islam untuk senantiasa berharap mendapatkan pemimpin-pemimpin yang bertakwa dan mampu diterima secara keseluruhan oleh umat Islam. Aspek kebersamaan pada salat, khususnya yang dilakukan secara berjemaah ini akan menghindarkan individu dari rasa keterasingan secara sosial. Sebab kondisi keterasingan secara psikologis akan menyebabkan individu bisa mengalami tekanan kejiwaan. ${ }^{32}$ Dengan salat apalagi yang dilakukan dengan berjemaah akan membuat orang tidak mengalami

${ }^{32}$ Ancok dan Suroso, Psikologi Islami. 100. keterasingan dan dia tidak merasa sendiri dalam berjuang membangun masyarakat takwa. Dengan kebersamaan/jemaah dalam salat seseorang akan membangun mampu membangun makna bahwa bukan dirinya saja yang mengalami penderitaan atau kebahagiaan, sehingga akan mendorong seseorang untuk senantiasa mencari makna hidupnya dan mensikapinya secara positif kehidupannya.

\section{f) unsur gerakan}

Gerakan-gerakan dalam salat yang diawali oleh takbiratul ikram, rukuk, bangkit dari rukuk, sujud dan duduk diantara dua sujud, tasyahud serta diakhiri dengan salam. Dalam gerakan-gerakan salat mengandung unsur relaksasi, hal ini bisa mengurangi tekanan-tekanan psikologis. Bahkan menurut Eugene Walker dalam penelitiaannya mengatakan bahwa olahraga mampu menghilangkan kecemasan. ${ }^{33}$ Maka gerakan-gerakan salat apalagi yang hampir tiap hari kita melakukannya tujuh belas rakaat dan jika masih ditambah dengan salat-salat sunnah lainnya seperti salat tahajud mungkin akan sama menghasilkan relaksasi sebagaimana orang olahraga, bahkan mungkin bisa lebih karena dalam salat bukan hanya aktivitas fisik tetapi juga psikis, sehingga mampu juga mengurangi kecemasan atau bahkan mungkin bisa menghilangkan kecemasan. ${ }^{34}$

Bukan hanya aspek olahraga, gerakan salat juga mengandung aspek meditasi, dan menurut Zurof, aspek meditasi juga mampu menghilangkan kecemasan. ${ }^{35}$ Maka orang yang mengerjakan salat bukannya melakukan gerakan-gerakan yang

\footnotetext{
33 Ibid., 98.

$34 \mathrm{lbid}$.

35 Ibid., 99.
} 
berpungsi untuk melakukan relaksasi secara fisik tetapi juga sekaligus melakukan relaksasi secara psikis. Aleksi Carel mengatakan, bahwa ketegangan dan kecemasan menyebabkan perubahan pada organ dan akan berefk pada kesehatan. Maka orang-orang yang beragama akan lebih mudah meraih ketenangan karena merasakan ada kedekatan dan ketergantungan kepada Tuhan. ${ }^{36}$ Ross Herfing mengatakan bahwa untuk terapi orang yang sedang mengalami tekanan jiwa dan untuk mengatasinya adalah dengan cara membawa orang tersebut kepada seseorang yang dipercaya, dimana kepadanya orang tersebut bisa mencurahkan keluh kesahnya ${ }^{37}$. inilah yang didalam salat seseorang baik secara individu ataupun secara berjemaah bisa mencurahkan isi hatinya, menyampaikan beban jiwanya kepada dzat yang maha agung dan maha berkuasa yang kekuasaanya meliputi alam raya dan seisinya dimana segala urusan kembali pada-Nya, sebagaimana firman Allah yang menyebutkan bahwa, kepunyaan Allah-lah segala yang ada di langit dan di bumi; dan kepada Allahlah dikembalikan segala urusan." ${ }^{\prime 38}$

Hal inilah yang ditekankan dalam Alquran surah Alfatihah ayat 5-7, yang menyatakan bahwa, hanya Engkaulah yang Kami sembah, ${ }^{39}$ dan hanya kepada Engkaulah Kami meminta pertolongan. ${ }^{40}$ Selain itu

\footnotetext{
${ }^{36}$ Aziz, 60 Menit., 199.

37 Ibid., 200.

38 QS. 3: 109.

${ }^{39} \mathrm{Na}$ 'budu diambil dari kata 'ibaadat: kepatuhan dan ketundukkan yang ditimbulkan oleh perasaan terhadap kebesaran Allah, sebagai Tuhan yang disembah, karena berkeyakinan bahwa Allah mempunyai kekuasaan yang mutlak terhadapnya.

${ }^{40}$ Nasta'iin (minta pertolongan), terambil dari kata isti'aanah: mengharapkan bantuan untuk dapat
}

juga ada ayat yang mengatakan bahwa, jadikanlah sabar dan salat sebagai penolongmu. dan Sesungguhnya yang demikian itu sungguh berat, kecuali bagi orang-orang yang khusyu. ${ }^{41}$ Dengan curahan hati yang telah disampaikan lewat bacaan penghambaan dan pangabdian serta permohonan doa, maka beban akibat tekanan perjuangan yang menghimpit jiwa menjadi ringan dan orang akan segar dan fresh jiwanya sehingga mampu berpikir, menyadari kesalahan atau mengalakukan instrospeksi diri dan memiliki optimisme yang kuat sebab dia merasa bersandar dengan dzat yang maha kuat. Allah memberikan jaminan dalam ayatnya yang berbunyi bahwa, dan barangsiapa yang menyerahkan dirinya kepada Allah, sedang Dia orang yang berbuat kebaikan, Maka Sesungguhnya ia telah berpegang kepada buhul tali yang kokoh, dan hanya kepada Allah-lah kesudahan segala urusan. ${ }^{42}$ Maka orang-orang beriman yang berserah diri kepada Allah dan tetap berbuat kebajikan maka, Allah akan memudahkan segala urusan yang membelitnya, termasuk persoalan tekanan kejiwaan.

Dari berbagai unsur dalam salat baik sebelum dan pada waktu salat merupakan sebuah aktivitas yang berdimensi relaksasi baik secara fisik, psikologis bahkan spritual, sehingga mampu membangkitkan kesadaran manusia untuk menatap tantangan kehidupan dengan penuh optimis, jauh dari sikap prustasi dan mendorong untuk mencari inspirasi dan solusi lewat jalan-jalan berpikir atau bertanya pada ahlinya. Dengan keyakinan

menyelesaikan suatu pekerjaan yang tidak sanggup dikerjakan dengan tenaga sendiri.

${ }^{41}$ QS. 2:45.

42 QS. 31: 22. 
dan percaya diri yang di dorong oleh baik bacaan maupun gerakan salat akan menimbulkan rasa optimis dalam menemukan makna hidup dari pekerjaan ataupun karya yang telah dihasilkan atau keadaan-keadaan yang sedang dialami dan akan dialami. Kondisi inilah yang mendorong seseorang yang melakukan salat akan mampu membangkitkan kesadaran dirinya dalam rangka menemukan makna hidupnya. Unsur gerakan secara tidak langsung akan membantu manager melakukan relaksasi sehingga ini akan membantunya untuk fokus pada peningkatan kesadaran dan menemukan makna hidupnya dalam setiap pekerjaan dan karyanya dan mendorong rasa percaya diri dalam menghadapi stressor.

Dari berbagai penjelasan diatas maka peranan salat dalam mengatasi problem psikologis manager dakwah terkait dengan membangkitkan kesadaran akan visi dan misi dakwah dan memberikan sebuah kepercayaan diri dalam menghadapi tekanan dan tantangan dakwah baik yang berasal dari internal organisasi dakwah ataupun kompetitor dan lingkungan. Kesadaran dan kepercayaan ini bisa diperoleh dari menghayati aktivitas salat. Dalam logotarapi salat bisa membantu seseorang memaknai hidupnya, memaknai pekerjaan atau karyanya, serta merubah sikap dari negatif menjadi positif, dari putus asa, menjadi optimis, dari rasa tekut, cemas mendajadi berani dan percaya diri. Karena hal-hal itulah yang dibutuhkan seorang manager dakwah dalam menghadapi berbagai tekanan psikologis yang menimpanya.

\section{Teknis Memfungsikan Salat untuk Mengatasi Hambatan Psikologis bagi Manajer Dakwah}

Disadari bahwa salat diketahui mampu menjadikan sebuah pemecahan masalahmasalah psikologis bersifat membuka kesadaran, sehingga tentunya akan mempengaruhi bagaimana teknisnya dalam menggunakan salat sebagai terapi bagi manager. Kalau dilihat dari unsur-unsur aktivitas dalam salat maka salat bagi kaum muslimin bisa menjadi media terapis dalam menghadapi tekanan-tekanan psikologis akibat pekerjaan-pekerjaan sebagai manager dakwah. Selain itu salat yang sudah menjadi rutinitas setiap hari diperintahkan menjalankannya sebanyak lima kali dalam lima waktu serta masih disunnahkan menjalankan salat tahajud disepertiga malam terakhir, sebagai upaya menyampaikan beban-benan psikologis maupun segala urusan yang sulit dipecahkan oleh seorang manajer.

Logoterapi adalah suatu terapi mengatasi hambatan psikologis dengan menemukan/mengubah makna dibalik bencana yang dialami dihubungkan dengan eksistensinya (makna hidupnya). Cara individu menemukan dan mengubah persepsi terhadap stressor yang akan mempengaruhi reaksi psikologisnya. Substansinya adalah cara berpikir terhadap stressor sebagaimana telah diuraikan sebelumnya. Dalam situasi yang demikian seorang, khususnya manager dakwah tidak mampu keluar dari masalah, sementara tekanan senantiasa menerpanya setiap saat dari berbagai penjuru. Hal ini akan menimbulkan munculnya pikiran-pikiran negatif dan menguasainya, sehingga 
manager akan sulit keluar dan hanya sibuk pada pikiran-pikiran negatif yang semakin lama-lama menguasai seluruh aspek kesadarannya. la akan kehilangan fokus untuk memecahkan masalah, tetapi bergeser pada soal-soal pinggiran dan larut dalam sulitnya masalah, bukan mencoba melihat masalah dari perspektif lain atau menjaga jarak dengan masalah, justru manager melibatkan secara perasaan dan pikiran serta terbelenggu dalam kesulitankesulitan yang ia hadapi. Pada posisi ini manager akan mengalami tekanan jiwa yang mendalam dan ia akan semakin mengalami stress dan jika terus-menerus akan bisa mangalami depresi hebat bahkan mungkin bisa kegilaan.

Prinsip dasar teknis memfungsikan salat untuk mengtasai hambatan psikologis manajer dakwah dapat digambarkan dalam empat langkah logoterapi, yaitu sebagai berikut, pertama, mengambil jarak atas simtom (distance from symptoms). Pendekatan ini berusaha mengajak seorang klein untuk keluar dari ketidakberdayaannya terhadap situasi yang membelitnya, dengan membuka pandangan baru diluar pandangannya dan mencoba untuk melihat beban persoalan itu sebagai sesuatu yang bisa diatasi dengan membuka kesadaran akan kemampuan yang lain yang dimilikinya. Dalam salat seorang diajak untuk membuka kesadaran dan mengakui ada dzat yang maha kuasa yang menguasai segala gerak dan kehidupan, dimana kepada-Nya semua makhluk bergantung. Dengan demikian seorang yang salat dia bisa mencurahkan seluruh beban jiwanya kepada dzat yang maha kuasa dan maha pemberi pertolongan. Terbukanya kesadaran maka manager bisa membuka pikiran yang kalut atas himpitan dan tekanan pekerjaaannya bisa membuka dan mengambil jarak dengan himpitan-himpitan tersebut dan tidak memandangnya hanya dengan satu perspektif. Terbukanya kesadaran akan membuat seseorang membuka pikirannya dan menghilangkan persepsi dan perasaan negatif dan menjaga jarak dengannya. Maka kesadaran pikirannya akan bergerak pada pikiran-pikiran positif dan mendorongnya lepas dari belenggu dan tekanan-tekanan jiwa. Terlepasnya tekanan ini membuat seseorang bergerak memikirkan alternatif-alternatif solusi yang lebih bervariasi dengan perspektif yang lebih kaya.

Kedua, modifikasi prilaku (modification of attitudes). Prinsip ini terkait dengan bagaimana seorang klein mampu membangun kepercayaan dirinya, sehingga mampu bersikap dengan penuh tanggungjawab. Maka seorang terapis diharapkan memberikan masukan sikap positif kepada kleinnya, bukan membiarkan dirinya semakin tidak percaya diri lantaran tidak mampu bersikap terhadap persoalan yang membelit perasaan dan jiwanya. Salat yang dikerjakan oleh seseorang dimana baik secara gerakan ataupun bacaan mengandung doa dan relaksasi akan mendorong seseorang yang melakukannya menjadi optimis, percaya diri karena dia bersandar pada dzat yang maha kuat. Rasa percaya diri akan muncul jika seorang menghayati adanya sesuatu yang maha agung dan maha sempurna yang memiliki kekuatan tak terhingga yang mem-back up dirinya. Situasi salat dimana seseorang merasa dirinya kecil dihadapan Allah penguasa alam, dan tidak ada suatu urusannya yang tidak kembali padaNya. Rasa optimis dan percaya diri akan menjadi 
seseorang berani bersikap dan bertanggujawab sehingga akan mengurangi rasa putus asa yang mungkin menekan jiwanya. Rasa percaya diri sangat diperlukan oleh seorang manager dakwah dalam menghadapi berbagai tekanan yang datang dari berbagai penjuru, khususnya juga tekanan pada kompetitor dan lingkungan dakwah.

Ketiga, pengurangan simtom (reducing simptoms). Tahap ini adalah upaya mengurangi beban-beban psikologis yang dirasakan oleh klien dan terapis membantunya untuk proses berkurangnya tekanan tersebut. Salat membuat seseorang merasa telah "curhat" kepada Allah dan menyerahkan segala beban dan urusannya kepada Allah, sehingga secara psikologis ia merasa dirinya plong, bebannya sudah berkurang, tekanantekanan dan masalah yang ia hadapi sudah disampaikan semua lewat do'a dan gerakan-gerakan relaksasi. Salat bagi manager dakwah bisa digunakan untuk merefresh kembali jiwanya dari tekanantekanan batin akibat tekanan pekerjaanpekerjaan ataupun kompetitor dan lingkungannya. Dengan berkurangnya beban psikologis dan terbuka kesadaran akan membantu pikiran untuk bisa kembali fresh, untuk memikirkan persoalanpersoalan yang dihadapi dengan kondisi yang lebih stabil dan siap dan penuh percaya diri untuk berusaha menemukan solusi atau alternatif solusi dengan kesabaran yang tinggi dan beban psikologis yang rendah. Mengurangi simtoms kecemasan menurut Dale Carnigie juga bisa dengan jalan menerima kenyataan atau keadaan yang memang kita tidak mampu untuk menghindarinya. Dalam bahasa Alquranadalah ikhlas menerima keadaan yang tidak bisa kita hindari atau memang harus kita hadapi sebagai konsekwensi dari sebuah perjuangan hidup. Untuk menemukan makna pada logoterapi setiap manusia memiliki kemampuan untuk mengambil sikap atau mengubah sikap terhadap penderitaan dan peristiwa yang tragis yang tidak mungkin mampu dirubahnya. Dengan salat kita tidak hanya mengurangi beban psikologis tetapi juga di arahkan untuk mengubah sikap dan mengambil sikap yang berbeda dengan yang sebelumnya.

Keempat, orientasi terhadap makna (Orientation toward Meaning). Tahap ini adalah tahap untuk mengembangkan dan memproduksi nilai-nilai dan pemaknaan tentang hidup, dan diperdalam serta diperluas untuk mencapai tujuan-tujuan yang lebih kongkret. Pada salat seorang muslim memang tidak dijanjikan dengan pasti sebuah pemecahan masalah atas keluhan yang disampaikan, tetapi salat memberikan kesempatan kepada seseorang untuk me-refresh kembali kesadaran dan pikirannya tentang tujuantujuan hidupnya. Dengan kondisi fresh akan mendorong kerja-kerja pikiran untuk melakukan langkah-langkah kongkret yang sudah direncanakan dengan melihat persoalan dan himpitan psikologis dari berbagai perspektif. Dalam kacamata manajemen ini bisa dikatakan sebagai kembali mengingat dan fokus pada visi dan misi serta tujuan-tujuan yang hendak dicapai, tidak terus larut pada satu masalah saja. Dale Carnigie memberikan salah satu cara untuk bisa menghentikan kecemasan adalah dengan menghitung karunia yang anda terima dan jangan menghitung 
kesulitan anda. ${ }^{43}$ Bagi manajer dakwah maka tahapan ini mendorong seseorang mengingat kembali akan visi, misi dan tujuan dia berdakwah. Sehingga tantangan sebesar apapun harus dihadapi dan itu merupakan sebuah konsekwensi logis dari perjuangan dakwah yang dilakukannya. Sehingga dari sini manager dakwah akan kembali bangkin dan berusaha menyusun kembali rencana-rencananya dan fokus pada masalahnya, bukan pada beban psikologis dan konsisten dalam mencapai visi dan misinya dalam berdakwah. Dalam logoterapi diajarkan bahwa manusia pada hakekatnya bertujuan menemukan makna hidupnya dengan meningkatkan kesadarannya. Sehingga dengan menemukan makna hidup seseorang akan mampu bersikap secara baik dalam keadaan sedih atau senang, bencana atau bahagia.

Adapun teknis memfungsikan salat sebagai terapis hambatan psikologis manajer dakwah, secara teknis salat yang dilakukan tidak berbeda dengan salat yang dilakukan kaum muslimin pada umumnya. Tetapi dengan melihat esensi, fungsi, dan peranan salat maka manager dakwah bisa memfungsikan salat sebagai sebuah terapi dalam menghadapi problem-problem psikologis yang sedang menimpanya. Aktivitas salat bisa menjadi sarana meningkatkan kesadaran dan kepercayaan diri untuk mensugesti lahirnya inspirasiinsipirasi dengan menjaga jarak terhadap masalah serta mendorong fokus pada masalah bukan pada beban-beban psikologinya. Secara teknis salat membantu manajer dakwah untuk menemukan tujuan

${ }^{43}$ Dale Carnigie, Bagaimana Menikmati Hidup Dan Mengatur Pekerjaan Anda, Bandung: Pioner, 1982, 201. hidupnya, memaknai apa yang sudah dikerjakan dan karya-karya yang sudah dihasilkan, serta mengubah sikap atau mengambil sikap yang positif dalam menghadapi stressor yang sedang dialaminya. Dengan demikian manajer dakwah bisa memfokuskan diri pada visi, misi dan program dakwah karena dalam setiap apa yang dikerjakan dan karyanya mengandung makna didalamnya. Keadaan seperti ini akan secara alamiah menghilangkan atau mengurangi stressor sehingga menjadi modal untuk mengurai masalah, menemukan pemecahan, membangun kepercayaan diri dan sebagainya.

\section{Kesimpulan}

Tanggung jawab besar, dinamika kerja, tantangan dan hambatan yang dihadapi manajer dakwah dalam mengelola organisasi dakwahnya akan menekan secara psikologis (menciptakan kejenuhan, ketakutan gagal/ancaman kompetitor) bahkan menimpulkan sikap keputus asaan, bila tidak tepat memaknai stressor tersebut. Manajer dakwah perlu memaknai stressor tersebut sebagai sesuatu yang bermakna (hukum alamiah untuk melakukan perubahan, akan mengantarkan ke cita-cita dan mendapatkan ganjaran surga) bukan sesuatu yang mengancam saja. Salat adalah sistem yang senantiasa memberikan kesadaran secara teratur melalui perbandingan antara: (a) besarnya/sulitnya hambatan dakwah dengan kebesaran/kekuasaan Allah; (b) kerasnya perjuangan dengan siksa neraka bila berputus asa dengan meninggalkan kewajiban berdakwah; (c) pengkondisian kebebasan lingkungan yang dapat melalaikan/meredupkan semangat dalam 
menyebarkan ajaran tauhid, dengan siksa jahanam dan jaminan surga bila tak pernah berputus asa dan konsisten dalam berdakwah.

Dalam teknis Salat terdapat mekanismemekanisme pembangkitan kesadaran makna dibalik kesulitan, bencana, ancaman yang dihadapi para manajer dakwah, meliputi: (a) doa untuk diberikan jalan yang lurus, keselamatan; (b) pujian yang senantiasa mengingatkan kebesaran, kekuasaaan, kasih sayang serta siksa neraka dan kebahagiaan akherat; (c) gerakan ketundukan, penghambaan hanya kepada Allah, bukan kepada segala makhluk yang dapat menghalangi jalan dakwah; (d) mendoakan nabi muhammad dan nabi ibrahim memiliki dampak psikologis menjadikan mereka sebagai idola, berharap bisa meneladani mereka dalam kesabaran dalam berjuang dan kesadaran bahwa kesulitan yang dihadapi dalam perjuangan merupakan hukum alamiah para pembaharu, sebagai mana dihadapi oleh para idola kita tersebut; (e) berjamaah, memberikan kesadaran kebersamaan dan kesatuan untuk bersama-sama menghadapi kesulitan yang ada, serta motivasi untuk tidak pernah meninggalkan para stafnya berjuang sendirian.

\section{Bibliografi}

Al-Warisy, Iskandar. "Potensi Unsur Sholat dalam Memecahkan Masalah" dalam Pemikiran Islam IImiah Buku II. Surabaya: Yayasan AI-Kahfi, 2012.

Ancok, Jamaluddin, dan Suroso, Fuat Nashori. Psikologi Islami: Solusi Islam atas ProblemProblem Psikologi, Yogyakarta: Pustaka Pelajar, 1995.

Aziz, Moh. Ali. 60 Menit Terapi Shalat Bahagia. Surabaya: IAIN Sunan Ampel Press, 2012.

Bastaman, Hanna Djumhana. Meraih Hidup Bermakna: Kisah Pribadi Dengan Pengalaman Tragis. Jakarta: Paramadina, 1996.

Burns, David D. Terapi Kognitif: Pendekatan Baru Bagi Penanganan Depresi. Diterjemahkan Santosa.Jakarta: Erlangga, 1988.

Carnigie, Dale. Bagaimana Menghilangkan Cemas \& Memulai Hidup Baru. Surabaya: Usaha Nasional, t.t. . Bagaimana Menikmati Hidup Dan Mengatur Pekerjaan Anda. Bandung: Pioner, 1982.

Departemen Agama RI (Depag RI), Alquran dan Terjemahannya.

Effendie, S. Anwar. Isra' Mi'raj: Perjalanan Ruang Waktu Dalam Kaitannya Dengan Penciptaan Alam Raya. Jakarta: Pradnya Paramita, 1993.

Gautama, Candra, Ed. Hidup Sehat bagi Eksekutif: Stress, Seks, dan Keluarga. Jakarta: Kompas, 2000.

Haikal, Muhammad Husain. Sejarah Hidup Muhammad. Diterjemahkan Ali Audah. Jakarta: Litera Antarnusa, 2010.

Koeswara, E. Logoterapi Psikoterapi Victor Frankl. Yogyakarta: Kanisius, 1992.

Pradesa, Dedy. "Dakwah Rasul Menjelang Hijrah: Strategi Dakwah Menghadapi Krisis," Jurnal Kajian dan Pengembangan Manajemen Dakwah, Vol. 06, No. 01, (Juni, 2016): 141-167. 